\title{
Clinical Reasoning: A 58-year-old man with hand tremor and episodes of neck pain
}

Daniele Urso, MD, Mariana H.G. Monje, MD, Rosanna Piredda, MD, Renato Ortu, MD, José A. Pineda-Pardo, PhD, Raul Martínez-Fernández, MD, PhD, and GianPietro Sechi, MD

Neurology ${ }^{\circledR}$ 2019;93:557-561. doi:10.1212/WNL.0000000000008130

\author{
Correspondence \\ Dr. Urso \\ danieleurso010@gmail.com
}

\section{Section 1}

A 58-year-old man presented with a 1-year history of progressive right-hand tremor and slowness of movement. Three months before admission, he developed notable loss of motivation and fluctuations in attention and cognition culminating in episodes of transient blank staring while he was unresponsive. He was able to perform the activities of daily living with some difficulties. In the month before presentation, he complained about episodes of moderate pain in the neck and shoulder on standing ("coat-hanger pain") and presented occasional and sudden episodes of transient loss of consciousness with falls. He also referred a 10-year previous history of hyposmia and dream-enacting behavior. Constipation, mostly nighttime urinary incontinence, and erectile dysfunction were reported to have started 3 years before. Medical history revealed myocardial infarction and depression with generalized anxiety disorder. His brother had been diagnosed with dementia at age 57 years and his father with Parkinson disease (PD) at age 60 years. Current medication included aspirin and bromazepam $3 \mathrm{mg} / \mathrm{d}$.

Neurologic examination showed hypomimia, mild right-hand "pill-rolling" rest tremor, rightside bradykinesia, and rigidity. He had reduced right arm swing when walking and shuffling gait with episodes of freezing during starting and turning. Cranial nerves, muscle strength, deep tendon reflexes, and sensorial and cerebellar systems were normal, and he had no postural instability on the pull test. He scored 21/30 points on Montreal Cognitive Assessment test, losing points mainly for impaired attentional and visuospatial functions. Clinical examination revealed a supine blood pressure of $130 / 80 \mathrm{~mm} \mathrm{Hg}$, with a fall of $50 \mathrm{~mm} \mathrm{Hg}$ in systolic and of $40 \mathrm{~mm} \mathrm{Hg}$ diastolic blood pressure within 3 minutes of standing, consistent with severe orthostatic hypotension.

\section{Questions for consideration:}

1. What is the differential diagnosis based on the clinical presentation?

2. What are the initial steps in evaluation?

\section{GO TO SECTION 2}



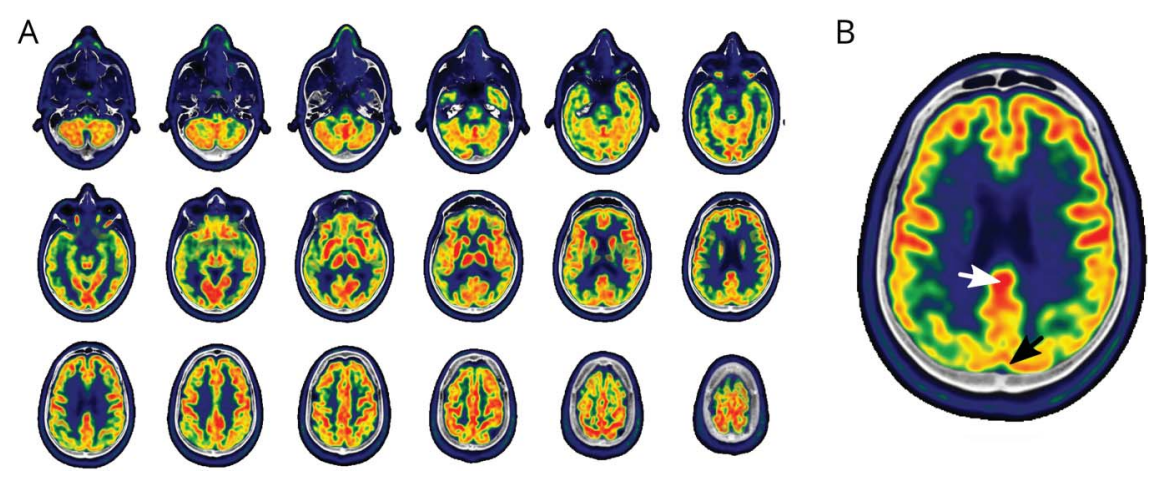

FDG-PET (A) shows significant diffuse reduced glucose metabolism in the temporo-occipital cortex, more pronounced in the left hemisphere and slightly reduced glucose metabolism in the frontoparietal, prefrontal, and posterior cingulate cortex. (B) The cingulate island sign reflects sparing of the posterior cingulate cortex (white arrow) relative to the precuneus and cuneus (black arrow).

\section{Section 2}

Bradykinesia with rest tremor and rigidity suggests a basal ganglia dysfunction involving the nigrostriatal pathway, with idiopathic PD being the most frequent cause. However, the patient presented early and severe autonomic failure (orthostatic hypotension, urinary incontinence, and erectile dysfunction). This feature is not usually present in the initial stages of PD, being in fact a "red flag" to suspect other causes of parkinsonism.

Among the causes of primary parkinsonism, those named "Atypical Parkinsonism" would be on the top of differential diagnosis. Prominent dysautonomia is the most important clinical manifestation of multiple system atrophy (MSA), whereas cognitive decline may be the presenting clinical feature of dementia with Lewy bodies (DLBs). Parkinson disease dementia (PDD) could be also considered, but according to clinical criteria, dementia should start 1 year or more after well-established PD. ${ }^{1}$

Parkinsonism with dysautonomia and cognitive impairment has also been described in a variety of heredodegenerative (such as familial PD, fragile $\mathrm{X}$ tremor ataxia syndrome, or DNA repeat expansion disorders, e.g., SCA 2 and SCA 3), and secondary conditions (such as vascular), but considering the prominent autonomic symptoms of the current case, these diagnoses seemed unlikely. ${ }^{2,3}$

Laboratory examinations, including complete blood tests, liver, kidney, thyroid function, and copper metabolism were normal. Brain MRI did not show a specific pathologic pattern of focal atrophy or signal intensity changes. $\left[{ }^{123} \mathrm{I}\right]$ FP-CIT SPECT (DaTSCAN) demonstrated almost absent bilateral binding in the putamen and marked uptake reduction in both caudates. EEG, recorded during alert wakefulness, showed a diffusely slowed and disorganized background activity in the theta and delta frequency ranges that would also be consistent with a primary dementing process.

Further ancillary investigations were performed to characterize the autonomic dysfunction and the cognitive impairment. Sympathetic skin response (SSR) was absent in the hand and foot. Sonography of the bladder revealed postvoid residual volume of $70 \mathrm{cc}$ of urine. $\left[{ }^{123} \mathrm{I}\right]$-meta-iodo-benzylguanidine ([ $\left.\left.{ }^{123} \mathrm{I}\right]-\mathrm{MIBG}\right)$ scan showed almost no cardiac uptake, in both the early and the late phase.

$\left[{ }^{18} \mathrm{~F}\right]$-labeled fluorodeoxyglucose PET study showed significant diffuse reduced glucose metabolism in the temporooccipital cortex, more pronounced in the left hemisphere and slightly reduced glucose metabolism in the frontoparietal, prefrontal, and posterior cingulate cortex (figure, A).

Formal neuropsychological assessment posed the diagnosis of dementia. It documented significant impairment in attentional, executive, and visuoperceptual domains. Memory tests (verbal list learning and story recalls) also revealed a moderate impairment. Language examination showed no deficits. Orthostatic hypotension was controlled during the neuropsychological test.

Finally, dopaminergic response was evaluated, showing mild improvement of motor features after levodopa intake $(300 \mathrm{mg}$ in combination with $75 \mathrm{mg}$ of carbidopa daily). However, the patient developed visual hallucinations requiring a decrease in levodopa dosage.

\section{Questions for consideration:}

1. How do you interpret these results?

2. What diagnoses would you consider at this point?

3. Which additional features on history could help redefine diagnosis? 


\section{Section 3}

Altogether, the diagnostic tests confirmed autonomic dysfunction, dopaminergic nigrostriatal deficit, and dementia with diffuse cortical hypometabolism predominantly in the temporooccipital cortex. At this point, MSA and DLB were the most plausible diagnosis, although some clinical features were atypical. Accurate diagnosis is important for optimal clinical management (e.g., neuroleptic agents should be avoided whenever possible in DLB, given the increased risk of a serious sensitivity reaction ${ }^{1}$ ) and early identification of signs and symptoms requiring intervention (e.g., nocturnal inspiratory stridor in MSA).

Early and severe autonomic failure is a key feature of MSA, with cardiovascular and urogenital systems the most affected. In fact, severe orthostatic hypotension is the main feature of cardiovascular autonomic symptoms. It can manifest as recurrent syncope, light-headedness, weakness, nausea, or coathanger pain, namely pain referred to suboccipital and shoulder region due to muscles hypoperfusion in upright postures. In MSA, cardiac dysautonomia is due to central autonomic failure. MIBG scintigraphy assesses postganglionic sympathetic innervation of the heart, which is impaired in PD and DLB and is typically normal in MSA. Nevertheless, the absence of cardiac MIBG uptake in our patient should be interpreted with caution because of the previous history of ischemic heart disease. Likewise, SSR is a measure of skin postganglionic sympathetic activity, assessing evoked electrodermal activity. It was impaired in this patient as it occurs in MSA compared with PD because of a more severe neuropathologic involvement of the autonomic nervous system.

Neuropsychological assessment revealed dementia. Although attentional and executive deficits have been reported, dementia is rare in MSA. The presence of dementia in the context of parkinsonism and autonomic failure should prompt consideration of DLB. ${ }^{4}$
DLB is clinically characterized by progressive cognitive decline with fluctuations in cognition and alertness, REM sleep behavior disorder, recurrent spontaneous visual hallucinations (typically complex and well formed), and parkinsonism. Dementia typically occurs before or within 1 year from the onset of motor symptoms, unlike PDD. Deficits on tests of attention, executive function, and visuoperceptual ability may be especially prominent. The patient fulfills the diagnostic criteria for probable DLB. Ancillary tests such as FDG-PET reinforce this diagnosis. Occipital hypometabolism and relative preservation of posterior or midcingulate metabolism (the cingulate island sign, figure, B) have been characteristically described in DLB. ${ }^{1,5}$

Nevertheless, some clinical features were uncommon for the above-mentioned diagnosis. The patient presented with early and severe orthostatic hypotension and asymmetric rest tremor. Autonomic dysfunction is a prevalent feature in DLB but is rarely as intense as in MSA and usually appears later in the course of the disease. Furthermore, pill-rolling rest tremor is less common than bradykinesia and is often symmetric in DLB. ${ }^{6}$ Because of these atypical features and considering the tempo of disease progression and the presence of a positive family history of neurologic disorders, we decided to delve deeper into his family background. $^{3}$

Clinical data for affected family members were obtained from medical records and proxy interviews. Three-generation pedigree consistent with an autosomal dominant pattern of disease inheritance was found. The clinical phenotype was characterized by early- or adult-onset parkinsonism with dysautonomia, dementia, and psychosis.

\section{Question for consideration:}

1. Which genetic testing would you consider first?

GO TO SECTION 4 


\section{Section 4}

Because of the prominence of parkinsonism in family history, SNCA and LRKK2 genes were focused. LRRK2 (PARK8) represents the most common genetic cause of PD. SNCA missense mutations (PARK1) and multiplications (PARK4) may associate parkinsonism with a broad clinical array of prominent nonmotor symptoms. ${ }^{7}$ Other genes have been proposed to mediate autosomal dominant forms of PD (VPS35, EIF4G1, DNAJC13, and $\mathrm{CHCHD2}$ ), but they are very infrequent, and for some, the pathogenic effect awaits confirmation. ${ }^{8}$

Genetic test with Multiplex Ligation-dependent Probe Amplification revealed SNCA gene heterozygous duplication. patients with SNCA duplications, and especially those with SNCA triplications, can display early-onset parkinsonism with a more aggressive course and prominent nonmotor features, such as severe dysautonomia, REM sleep behavior disorder (RBD), hallucinations, and dementia. ${ }^{2}$ The nonmotor features of SNCA duplications resemble the nonmotor phenotype commonly seen in other alpha-synucleinopathies such as MSA or, more frequently, DLB. It suggests that the different clinical phenotypes are on a spectrum of an underlying geneticpathologic entity.

SNCA testing should be considered in the differential diagnosis of autosomal dominant parkinsonism with prominent

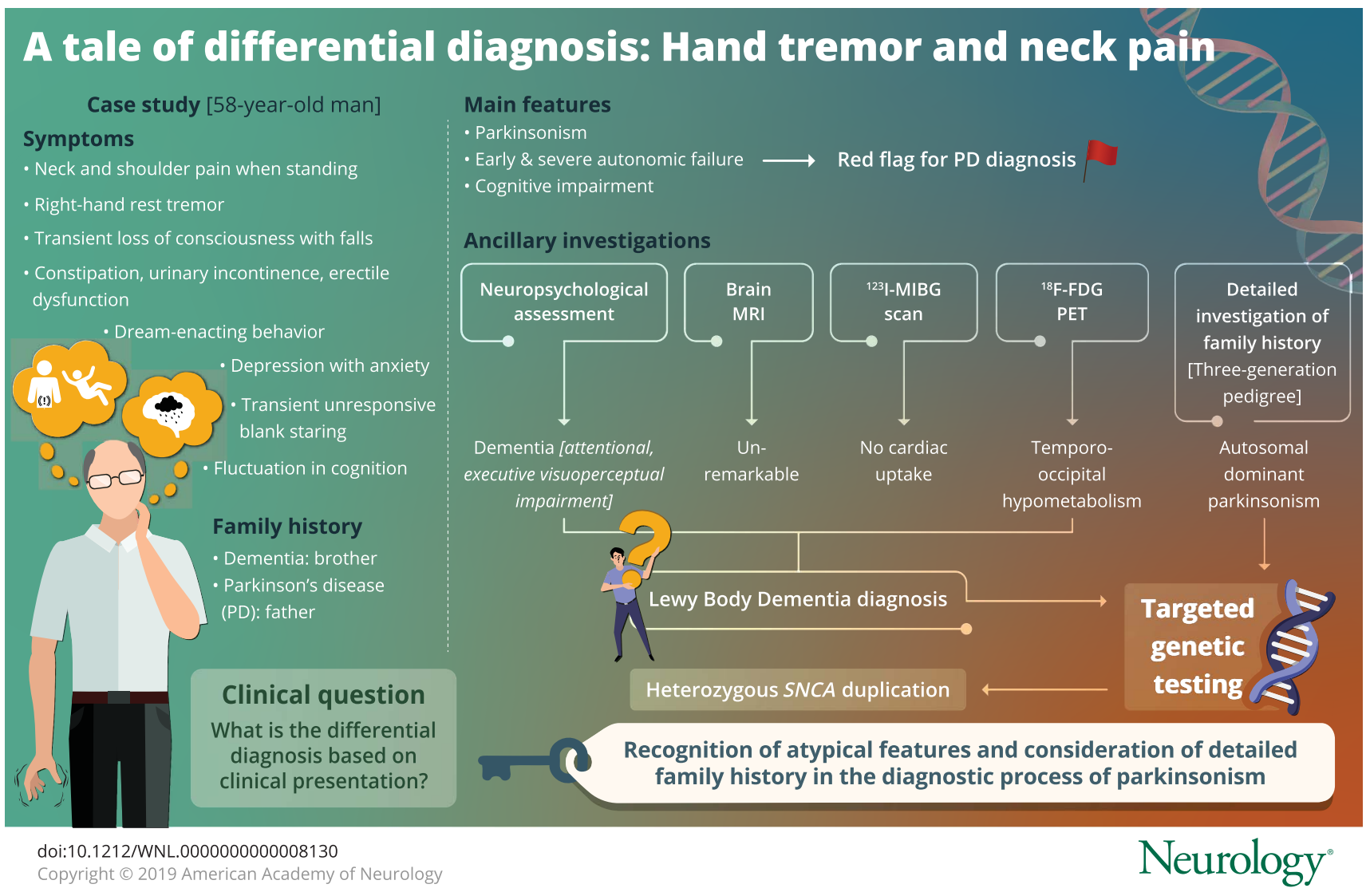

\section{Discussion}

\section{SNCA duplications}

SNCA duplications are detected in approximately $1 \%-2 \%$ of the PD families with an autosomal dominant pattern of inheritance. ${ }^{9}$ Some patients showed typical PD phenotype, although wide clinical variability regarding age at onset, symptoms, disease progression, and levodopa response had been observed even within a single family. ${ }^{10}$

The clinical phenotype may be dependent on the presence of extra copies of the SNCA gene resulting in pathogenic overexpression of wild-type alpha-synuclein. Therefore, and heterogeneous nonmotor symptoms. This case highlights (1) a description of a new case of SNCA duplication, (2) the importance of recognizing "atypical" features and reconsidering family history in the diagnostic process of parkinsonism, and (3) that the accurate phenotypic definition can assist to guide cost-effective prioritization of genetic testing.

Future descriptions and studies on additional families with SNCA multiplications may help to understand the role of alpha-synuclein in PD pathogenesis.

\section{Acknowledgment}

The authors thank J.A. Obeso for reviewing the manuscript. 


\section{Study funding}

No targeted funding reported.

\section{Disclosure}

D. Urso, M. Monje, R. Piredda, R. Ortu, and J. Pineda-Pardo report no disclosures relevant to the manuscript. R. MartínezFernandez-reports honoraria for lecturing from Teva, Zambon, and Alter and payment to attend scientific meetings from Boston Scientifics, Insightec, Alter, Zambon, and General Electric. G. Sechi reports no disclosures relevant to the manuscript. Go to Neurology.org/N for full disclosures.

\begin{tabular}{llll} 
Appendix & Authors & & \\
\hline Name & Location & Role & Contribution \\
\hline $\begin{array}{l}\text { Daniele } \\
\text { Urso }\end{array}$ & $\begin{array}{l}\text { University of } \\
\text { Sassari, } \\
\text { Sassari }\end{array}$ & Author & $\begin{array}{l}\text { Drafted and revised the } \\
\text { manuscript; analyzed and } \\
\text { interpreted data }\end{array}$ \\
$\begin{array}{l}\text { Mariana } \\
\text { H.G. Monje }\end{array}$ & $\begin{array}{l}\text { University } \\
\text { Hospital HM, }\end{array}$ & Author & $\begin{array}{l}\text { Performed critical revision of } \\
\text { the manuscript for intellectual } \\
\text { content }\end{array}$ \\
\hline $\begin{array}{l}\text { Rosanna } \\
\text { Piredda }\end{array}$ & $\begin{array}{l}\text { University of } \\
\text { Sassari, } \\
\text { Sassari }\end{array}$ & Author & $\begin{array}{l}\text { Performed critical revision of } \\
\text { the manuscript for intellectual } \\
\text { content }\end{array}$ \\
\hline $\begin{array}{l}\text { Renato } \\
\text { Ortu }\end{array}$ & $\begin{array}{l}\text { University of } \\
\text { Sassari, } \\
\text { Sassari }\end{array}$ & Author & $\begin{array}{l}\text { Performed critical revision of } \\
\text { the manuscript for intellectual } \\
\text { content }\end{array}$ \\
\hline
\end{tabular}

\begin{tabular}{llll} 
Appendix & (continued) & & \\
\hline Name & Location & Role & Contribution \\
\hline $\begin{array}{l}\text { José A. } \\
\text { Pineda- } \\
\text { Pardo }\end{array}$ & $\begin{array}{l}\text { University } \\
\text { Hospital HM, } \\
\text { Madrid }\end{array}$ & Author & Analyzed and interpreted data \\
\hline $\begin{array}{l}\text { Raul } \\
\text { Martínez- } \\
\text { Fernández }\end{array}$ & $\begin{array}{l}\text { University } \\
\text { Hospital HM, } \\
\text { Madrid }\end{array}$ & Author & $\begin{array}{l}\text { Performed critical revision of } \\
\text { the manuscript for intellectual } \\
\text { content }\end{array}$ \\
\hline $\begin{array}{l}\text { GianPietro } \\
\text { Sechi }\end{array}$ & $\begin{array}{l}\text { University of } \\
\text { Sassari, } \\
\text { Sassari }\end{array}$ & Author & $\begin{array}{l}\text { Revised the manuscript and } \\
\text { approved all final changes }\end{array}$ \\
\hline
\end{tabular}

\section{References}

1. McKeith IG, Boeve BF, Dickson DW, et al. Diagnosis and management of dementia with Lewy bodies: fourth consensus report of the DLB Consortium. Neurology 2017;89:88-100.

2. Fuchs J, Nilsson C, Kachergus J, et al. Phenotypic variation in a large Swedish pedigree due to SNCA duplication and triplication. Neurology 2007;68:916-922.

3. Stamelou M, Quinn NP, Bhatia KP. Atypical atypical parkinsonism: new genetic conditions presenting with features of progressive supranuclear palsy, corticobasal degeneration, or multiple system atrophy-a diagnostic guide. Mov Disord 2013;28:1184-1199.

4. Fanciulli A, Wenning GK. Multiple-system atrophy. N Engl J Med 2015;372:249-263.

5. Graff-Radford J, Murray ME, Lowe VJ, et al. Dementia with Lewy bodies basis of cingulate island sign. Neurology 2014;83:801-809.

6. Gomperts SN. Lewy body dementias: dementia with Lewy bodies and Parkinson disease dementia. Continuum 2016;22:435-463.

7. Bonifati V. Genetics of Parkinson's disease - state of the art, 2013. Parkinsonism Relat Disord 2014;20(suppl 1):S23-S28.

8. Kalia LV, Lang AE. Parkinson's disease. Lancet 2015;386:896-912.

9. Ibáñez $P$, Lesage $S$, Janin $S$, et al. Alpha-synuclein gene rearrangements in dominantly inherited parkinsonism: frequency, phenotype, and mechanisms. Arch Neurol 2009; 66:102-108.

10. Konno T, Ross OA, Puschmann A, Dickson DW, Wszolek ZK. Autosomal dominant Parkinson's disease caused by SNCA duplications. Parkinsonism Relat Disord 2016; 22(suppl 1):S1-S6.

\section{AAN Online Learning Center}

Browse a variety of online CME, self-assessment, and other learning activities to suit your wide-ranging interests and learning styles. Visit Learning.AAN.com today to access the Online Learning Center, your exclusive member-only hub for AAN continuing medical education.

\section{Diversity Leadership Program Opportunity with Personalized Coaching!}

Diversity and inclusion are essential to the AAN's—and neurology's—success. Apply for the 2020 Diversity Leadership Program to receive personalized coaching and leadership development training to help you build self-confidence, enhance relationships and comradery, reduce burnout, and enhance presentation and management skills. Visit AAN.com/membership/ diversity-leadership before October 11. 


\section{Neurology}

Clinical Reasoning: A 58-year-old man with hand tremor and episodes of neck pain Daniele Urso, Mariana H.G. Monje, Rosanna Piredda, et al. Neurology 2019;93;557-561

DOI 10.1212/WNL.0000000000008130

This information is current as of September 16, 2019

$\begin{array}{ll}\begin{array}{l}\text { Updated Information \& } \\ \text { Services }\end{array} & \begin{array}{l}\text { including high resolution figures, can be found at: } \\ \text { http://n.neurology.org/content/93/12/557.full }\end{array} \\ \text { References } & \text { This article cites } 10 \text { articles, } 3 \text { of which you can access for free at: } \\ & \text { http://n.neurology.org/content/93/12/557.full\#ref-list-1 } \\ \text { Subspecialty Collections } & \text { This article, along with others on similar topics, appears in the } \\ & \text { following collection(s): } \\ \text { Autonomic diseases } \\ \text { http://n.neurology.org/cgi/collection/autonomic_diseases } \\ \text { Dementia with Lewy bodies } \\ \text { http://n.neurology.org/cgi/collection/dementia_with_lewy_bodies } \\ \text { Parkinson's disease/Parkinsonism } \\ \text { http://n.neurology.org/cgi/collection/parkinsons_disease_parkinsonism } \\ \text { Information about reproducing this article in parts (figures,tables) or in } \\ \text { its entirety can be found online at: } \\ \text { http://www.neurology.org/about/about_the_journal\#permissions } \\ \text { Information about ordering reprints can be found online: } \\ \text { http://n.neurology.org/subscribers/advertise }\end{array}$

Neurology ${ }^{\circledR}$ is the official journal of the American Academy of Neurology. Published continuously since 1951, it is now a weekly with 48 issues per year. Copyright @ 2019 American Academy of Neurology. All rights reserved. Print ISSN: 0028-3878. Online ISSN: 1526-632X.

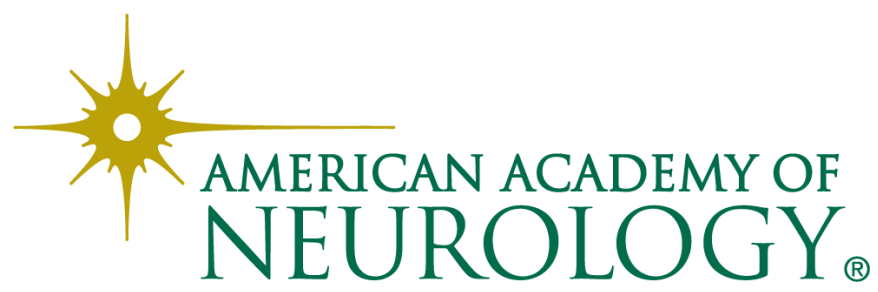

